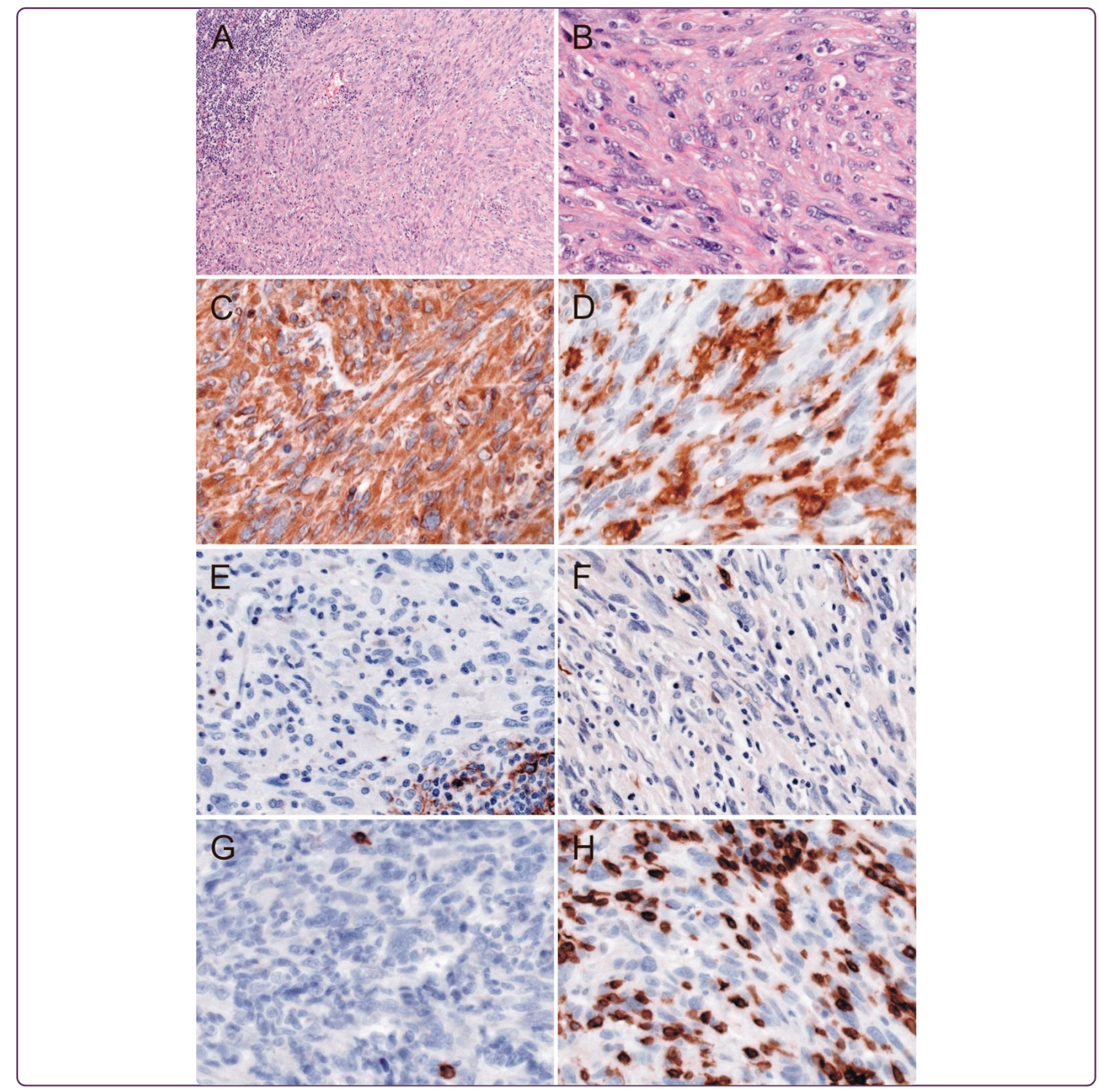

\title{
Dendritic cell tumor in a salivary gland lymph node: a rare differential diagnosis of salivary gland neoplasms
}

Schraven et al. 


\title{
Dendritic cell tumor in a salivary gland lymph node: a rare differential diagnosis of salivary gland neoplasms
}

\author{
Sebastian P Schraven ${ }^{1,5^{*}}$, Stefan K Plontke ${ }^{2}$, Roland Syha ${ }^{3}$, Falko Fend ${ }^{4}$, Hartwig Wolburg ${ }^{4}$ and Patrick Adam ${ }^{4}$
}

\begin{abstract}
Dendritic cell tumors are extremely rare neoplasms arising from antigen-presenting cells of the immune system. We report a case of a 69-year-old man with an unremarkable medical history who presented with a 2-months history of a gradually enlarging painless, firm, mobile, $2 \times 2-\mathrm{cm}$ swelling at the caudal pole of the left parotid gland without systemic symptoms. Histologically, the tumor consisted of a spindle cell proliferation in an intraparotideal lymph node. Based on the histopathologic, immunohistochemical and electron microscopic findings, a dendritic cell tumor, not otherwise specified (NOS) in an intraparotideal lymph node was diagnosed. The patient underwent complete tumor resection, and is currently free of disease, 2 years after surgery. These extremely rare tumors must be distinguished from other more common tumors in the salivary glands. Awareness that dendritic cell tumors may occur in this localization, careful histologic evaluation and ancillary immunohistochemical and electron microscopical analyses should allow for recognition of this entity.
\end{abstract}

Virtual Slides: The virtual slide(s) for this article can be found here: http://www.diagnosticpathology.diagnomx.eu/ vs/1614859498581601.

Keywords: Dendritic cell tumor, salivary gland lymph node

\section{Background}

Dendritic cell sarcomas (DCS) are exceedingly rare entities, arising from antigen-presenting cells of the immune system. DCS are subclassified into the better characterized follicular (FDCS) [1] and interdigitating (IDCS) [2] dendritic cell sarcomas and other rare and less well classifiable dendritic cell tumors like fibroblastic reticular cell tumors, indeterminate dendritic cell tumors and dendritic cell tumors, not otherwise specified (DCT, NOS) [2]. DCS was first described in 1986 by Monda et al. [3]. Since then, nearly 300 cases, most of them FDCS, have been described in the literature. Although most DCS evolve in cervical, mediastinal, axillary and inguinal lymph nodes, also extranodal manifestations have been described [4]. The clinical behaviour of DCS is similar to that of low-grade soft tissue sarcoma, with an approximately $30 \%$ overall risk for developing local

\footnotetext{
* Correspondence: schraven_s@klinik.uni-wuerzburg.de 'Department of Otolaryngology, Head and Neck Surgery, University of Tübingen, Elfriede-Aulhorn-Straße 5, D-72076 Tübingen, Germany Full list of author information is available at the end of the article
}

recurrences and metastases [5]. Because of the rareness of the disease a standardized treatment is lacking.

We herein report a case of a dendritic cell tumor, NOS of an intraparotideal lymph node, emphasizing the important role of ancillary immunohistochemical and molecular studies in establishing this extraordinarily rare diagnosis.

\section{Case report}

A 69-year-old man presented with a 2-months history of a gradually enlarging painless, firm, mobile, $2 \times 2 \times 2$ $\mathrm{cm}$ swelling at the caudal pole of the left parotid gland without systemic symptoms. His medical history was unremarkable.

Magnet resonance imaging (MRI) showed a $2 \times 2 \times 2$ $\mathrm{cm}$ mass with hyperintense signal on T2-weighted images and hypointense signal on T1-weighted sequences and a contrast enhancement which bordered directly to the lateral part of left sternocleidomastoid muscle and displaced the external jugular vein dorsally. Cranially there was no clear demarcation to the left

\section{C) Biomed Central}


parotid gland (Figure 1). The patient underwent surgical excision of the swelling by a partial left parotidectomy with preservation of the facial nerve. Because of insecure R0-status a follow-up resection with extended partial parotidectomy and ipsilateral selective neck dissection (levels II and III) was conducted. A primary tumor of the upper aerodigestive tract was excluded by panendoscopy. Subsequent total body positron emission tomography with 18-F-fluorodesoxyglucose and computed tomography scan 6 months after surgery were unremarkable. The patient is currently disease free, 2 years after surgery.

\section{Material and methods}

The specimen was fixed in 10\% buffered formalin, paraffin-embedded, and histologic sections were obtained. Sections were routinely stained with hematoxylin and eosin. Immunohistochemical staining was performed on formalin-fixed, paraffin-embedded tissue sections on an automated immunostainer (Ventana Medical Systems ${ }^{\odot}$, Tucson AZ) following the manufacturer's protocols. The monoclonal antibodies used are listed in Table 1.

For electron microscopical (EM) evaluation, small pieces of tissue were dissected out of the paraffin bloc, rehydrated stepwise and postfixed in $1 \% \mathrm{OsO}_{4}$ in 0.1 $\mathrm{M}$ cacodylate buffer ( $\mathrm{pH}$ 7.4) and then again

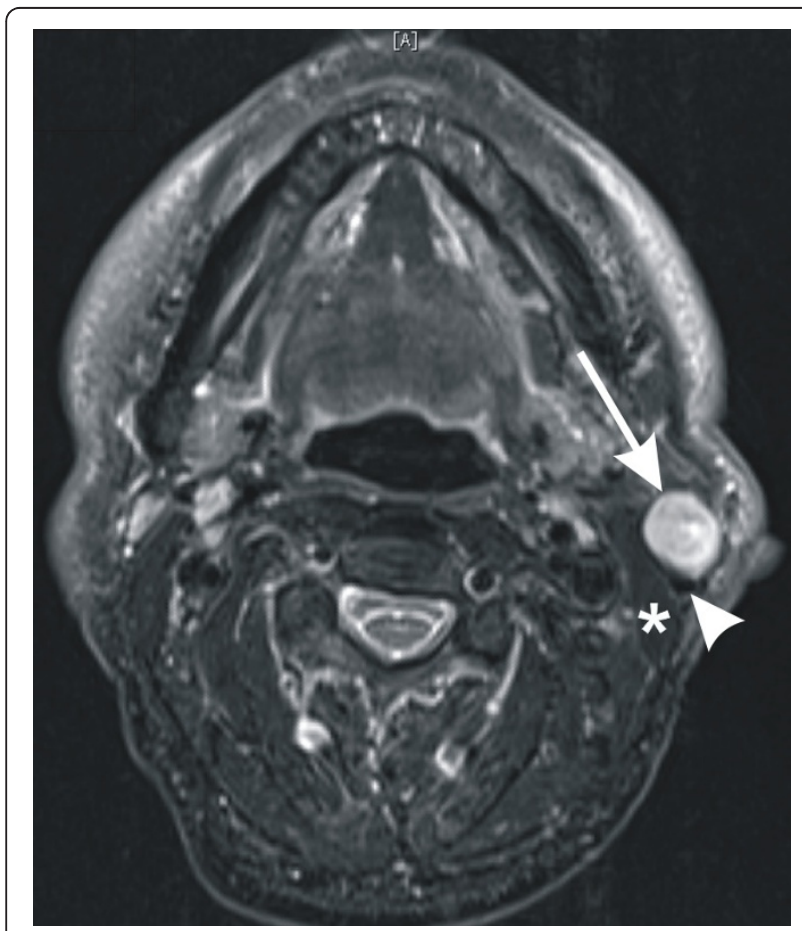

Figure 1 Axial MR image. (T2-weighted) of a $2 \times 2 \mathrm{~cm}$ mass with hyperintense signal (arrow) directly bordering the lateral part of left sternocleidomastoid muscle (asterisk) and displacing the extern jugular vein (arrow head) dorsally. Cranially there was no clear demarcation to the left parotid gland.
Table 1 List of antibodies and staining results.

\begin{tabular}{|c|c|c|c|}
\hline Antibody & Company & Dilution & Tumor cells \\
\hline Vimentin & DAKO & $1: 1000$ & positive \\
\hline HLA-DR & DAKO & $1: 200$ & part.positive \\
\hline Fascin & Abcam & $1: 100$ & positive \\
\hline Langerin & eBioscience & $1: 50$ & negative \\
\hline Lysozym & DAKO & $1: 400$ & negative \\
\hline $\mathrm{S} 100$ & DAKO & $1: 5000$ & negative \\
\hline $\mathrm{AE} 1 / 3$ & DAKO & 1:100 & negative \\
\hline HMB45 & DAKO & $1: 50$ & negative \\
\hline MITF & Zytomed & 1:100 & negative \\
\hline PMZ & Zytomed & $1: 50$ & negative \\
\hline LCA & DAKO & $1: 500$ & negative \\
\hline Calponin & DAKO & $1: 200$ & negative \\
\hline Caldesmon & DAKO & $1: 50$ & negative \\
\hline Clusterin & Menarini & $1: 30$ & negative \\
\hline EMA & DAKO & $1: 100$ & negative \\
\hline SMA & DAKO & $1: 500$ & negative \\
\hline CK5/6 & DAKO & $1: 100$ & negative \\
\hline CK8/18 & Zytomed & $1: 100$ & negative \\
\hline OSCAR & Zytomed & $1: 200$ & negative \\
\hline Synaptophysin & DCS & $1: 200$ & negative \\
\hline Chromogranin & DAKO & $1: 500$ & negative \\
\hline Factor XIIla & DCS & 1:100 & negative \\
\hline CD1a & DAKO & $1: 50$ & negative \\
\hline CD3 & Santa Cruz & $1: 200$ & negative \\
\hline CD4 & Zytomed & $1: 200$ & negative \\
\hline CD20 & DAKO & $1: 500$ & negative \\
\hline CD21 & Zytomed & $1: 50$ & negative \\
\hline CD23 & Novocastra & $1: 30$ & negative \\
\hline CD30 & DAKO & $1: 50$ & negative \\
\hline CD31 & DAKO & 1:100 & negative \\
\hline CD34 & DAKO & $1: 50$ & negative \\
\hline CD35 & Novocastra & $1: 50$ & negative \\
\hline CD56 & Cell Marque & 1:100 & negative \\
\hline CD68 (PG-M1) & DAKO & $1: 200$ & negative \\
\hline CD117 & DAKO & $1: 200$ & negative \\
\hline CD123 & BD Pharmingen & $1: 50$ & negative \\
\hline Mib1 & DAKO & $1: 200$ & $40-50 \%$ \\
\hline
\end{tabular}

dehydrated in an ethanol series (50,70, 96, 100\%). The $70 \%$ ethanol was saturated with uranyl acetate for contrast enhancement. Dehydration was completed in propylene oxide. The specimens were embedded in Araldite $\left(\right.$ Serva $^{\circ}$, Heidelberg, Germany). Ultrathin sections were produced on a FCR Reichert Ultracut ultramicrotome (Leica ${ }^{\odot}$, Bensheim, Germany), mounted on pioloform-coated copper grids, contrasted with lead citrate and analyzed and documented with an EM10A 
electron microscope (Carl Zeiss ${ }^{\odot}$, Oberkochen, Germany). The pictures were digitized and processed with Adobe Photoshop.

\section{Results}

\section{Gross and histological findings}

The specimen consisted of parotid gland tissue containing a single firm, nodule $2.3 \mathrm{~cm}$ in diameter. The cut surface was soft and homogeneous light-grey. Microscopic examination revealed a spindle cell neoplasia in an intraparotideal lymph node. Tumor cells featured moderate nuclear pleomorphism, bulked chromatin and a clearly perceptible nucleolus (Figure 2A, B). Furthermore an elevated mitotic rate (up to 27 mitoses per 10 high power fields) was found.

\section{Immunohistochemical Findings}

To further characterize the histogenesis of this tumor, immunohistochemical stainings were performed. The tumor cells were positive for vimentin, fascin and HLA-

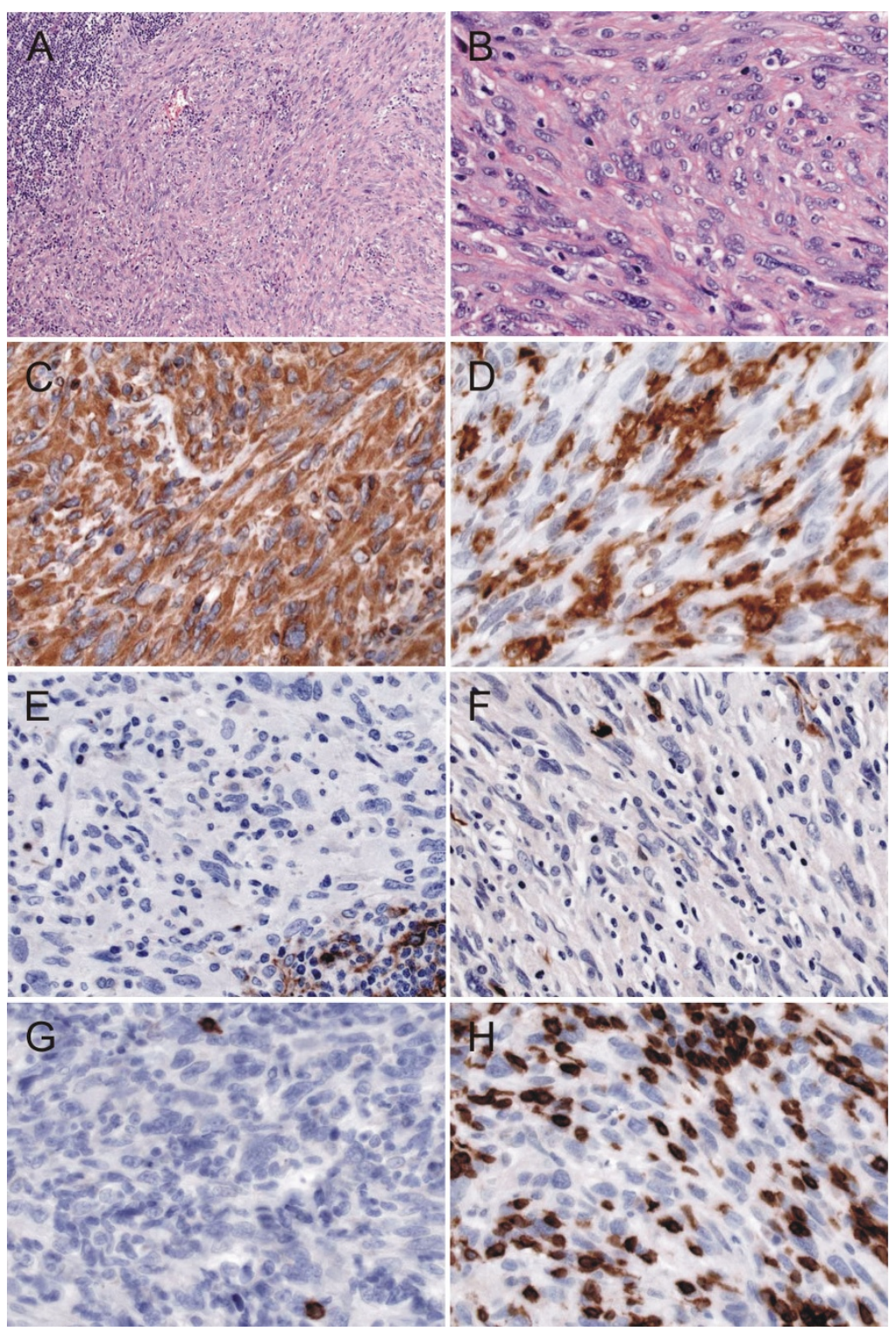

Figure 2 Morphology and immunohistochemical stainings: (A) H\&E (original magnification 100x) and (B) H\&E (original magnification 400x) show a spindle cell proliferation in an intraparotideal lymph node with moderate cellular pleomorphy (C) Vimentin (original magnification 400X) and (D)HLA-DR (original magnification 400X) were strongly expressed by the tumor cells. (E) Clusterin (original magnification 400x) and (F) S100 protein (original magnification 400x) were negative in the tumor cells. (G)CD20 showed only very few reactive small B-cells (original magnification 400x) and (H) CD3 some reactive T-lymphocytes (original magnification 400x). 
DR (Figure 2B, D). In contrast, the neoplastic cells were negative for all epithelial, melanocytic, lymphoid, histocytic and follicular dendritic cell markers used. The proliferation, as assessed by Mib1 index was $40-50 \%$. The results of the immuohistochemical stainings are shown in table 1.

\section{Electron Microscopic Findings}

The electron microscopical aspect of the tissue was characterized by cells which were devoid of characteristic structures as desmosomes or Birbeck granules. There was a certain heterogeneity of nuclei concerning their amount of heterochromatin. However, the cytoplasm of the cells (size, content of mitochondria or endoplasmatic reticulum) was less well differentiated (Figure 3A). The most prominent finding was the large number of slender long-spacing collagen fibers dividing the tissue in many compartments (Figure 3A). Fibrous long-spacing collagen the period length of which was in the order of $200 \mathrm{~nm}$ in this case (Figure 3B), is not described in the literature to be specific for any disease, but has been found in a variety of normal and pathological tissues. Therefore, it cannot be used as a pathognomonic marker here.

In summary, the morphological and immunophenotypic features were consistent with a dendritic cell tumor, not otherwise specified (NOS) originating in an intraparotideal lymph node. A differentiation towards a follicular or interdigitating dendritic cell sarcoma could not be demonstrated.

\section{Conclusions}

Dendritic cell sarcomas (DCS) are rare neoplasms arising from antigen-presenting cells of the immune system [2]. DCS are being recognized with an increasing frequency. These tumors can occur, where dendritic cells are located. One of the most common manifestation sites are the head and neck region. Under-recognition of this entity may contribute to its rarity. The WHO subclassifies DCS into five groups [2]: Langerhans cell histiocytosis, Langerhans cell sarcoma, interdigitating dendritic cell sarcoma (IDCS), follicular dendritic cell sarcoma (FDCS) and other rare and less well classifiable dendritic cell tumors like fibroblastic reticular cell tumors, indeterminate dendritic cell tumors and dendritic cell tumors, not otherwise specified (DCT, NOS) [2]. FDCS is the most common subtype followed by IDCS.

The clinical course of this neoplasia is similar to that of soft tissue sarcomas $[3,6]$. Since only 306 cases of DCS have been reported worldwide (table 2), there is no general consensus on the treatment of this rare disease. Surgery has remained the gold standard in localized disease, but a recurrence rate up to $50 \%$ has been reported [5]. Alternatively some DCS have also been treated additionally by radiotherapy and or chemotherapy [7]. For our patient we chose the option of surgical therapy and

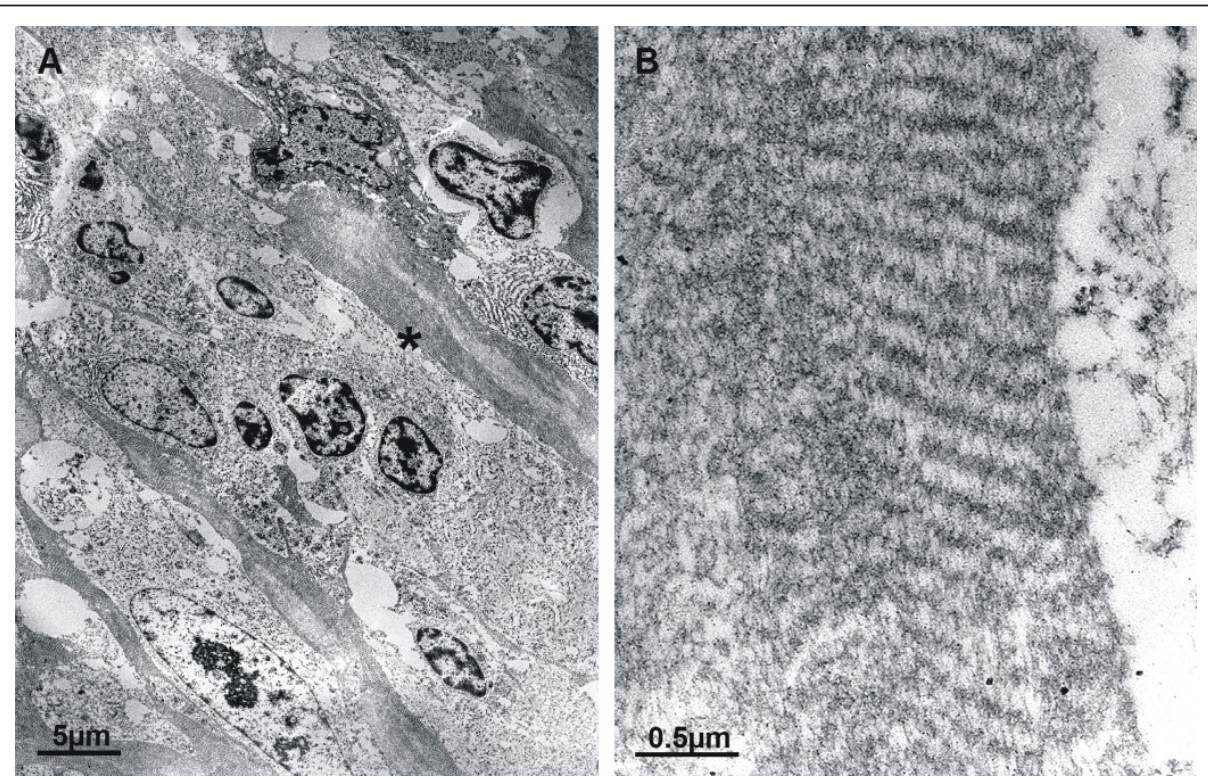

Figure 3 Electron microscopy (EM): Most prominent feature was the large number of slender long-spacing collagen fibers dividing the tissue in many compartments (A). Fibrous long-spacing collagen the period length of which was in the order of $200 \mathrm{~nm}$ in this case (B), is not described in the literature to be specific for any disease, but has been found in a variety of normal and pathological tissues. Well-formed desmosomes or Birbeck granules were not found in this case. 
Table 2 Overview of dendritic cell sarcoma case reports.

\begin{tabular}{lccl}
\hline \multicolumn{3}{l}{ FDCS } & IDCS \\
\hline $1986-4 / 2007 *$ & & \\
\hline Nodal & 77 & 33 & 110 \\
Extranodal & 52 & 22 & 74 \\
\hline $5 / 2007-08 / 2011[5,7,10-86]$ & & & \\
\hline Nodal & 68 & 14 & 82 \\
Extranodal & 33 & 7 & 40 \\
\hline & 230 & 76 & 306
\end{tabular}

FDCS, follicular dendritic cell sarcoma; IDCS, interdigitating cell sarcoma. * Modified from [5]. A total of 145 nodal FDCS cases, 85 extranodal FDCS cases, 47 nodal IDCS cases and 29 extranodal cases have been reported until 08/ 2011. 2 cases FDCS and 2 cases of IDCS occured in the parotid gland.

he is well and free of disease for 2 years after surgery now.

For establishing the diagnosis a large number of immunohistochemical stainings and ultrastructural analyses has been performed. Other rare differential diagnosis of salivary glands, like lipomatous pleomorphic adenoma [8] or sebaceous adenoma [9], were excluded. Despite this extensive work-up a definite assignation to an established entity of dendritic cell tumors could not be achieved. Therefore a diagnosis of dendritic cell tumor, NOS was made.

In summary, we report on the clinical, pathologic, and immunohistochemical features of a dendritic cell tumor, NOS in an intraparotideal lymph node. Metastatic disease was ruled out by PET- and CT imaging. Recognition of this extremely rare tumor, and its distinction from more common malignant tumors of lymph nodes and salivary glands largely depends on judicious application of immunohistochemical and ultrastructural techniques. The precise histogenesis of these extraordinarily rare tumors remains to be established.

\section{Consent}

Written informed consent was obtained from the patient for publication of this Case Report and any accompanying images. A copy of the written consent is available for review by the Editor-in-Chief of this journal.

\section{Acknowledgements}

This publication was funded by the German Research Foundation (DFG) and the University of Wuerzburg in the funding programme Open Access Publishing.

\section{Author details}

'Department of Otolaryngology, Head and Neck Surgery, University of Tübingen, Elfriede-Aulhorn-Straße 5, D-72076 Tübingen, Germany. ${ }^{2}$ Department of Otolaryngology, Head and Neck Surgery, University of HalleWittenberg, Magdeburger Straße 12, D-06112 Halle (Saale), Germany. ${ }^{3}$ Department of Diagnostic and Interventional Radiology, University of Tübingen, Hoppe-Seyler-Straße 3, D-72076 Tübingen, Germany. ${ }^{4}$ Institute of Pathology and Comprehensive Cancer Center (CCC), University of Tübingen, Liebermeisterstraße 8, D-72076 Tübingen, Germany. ${ }^{5}$ University of Würzburg,
Department of Otolaryngology, Head and Neck Surgery, Josef-SchneiderStrasse 11, 97080 Würzburg, Germany.

\section{Authors' contributions}

SPS SKP and RS designed the study, collected the clinical data and drafted the manuscript. HW carried out the electron microscopic analyses. FF and PA performed the histopathologic and immunohistochemical analyses and helped to draft the manuscript. All authors read and approved the final manuscript.

\section{Competing interests}

The authors declare that they have no competing interests.

Received: 3 August 2011 Accepted: 30 September 2011

Published: 30 September 2011

\section{References}

1. Chan JKC: Follicular dendritic cell sarcoma. WHO Classification of tumors of haematopoietic and lymphoid tissue WHO; 2008, 363-364

2. Weiss $L M G, T M$, Chan JKC: Interdigitating dendritic cell sarcoma. 2008.

3. Monda $L$, Warnke $R$, Rosai J: A primary lymph node malignancy with features suggestive of dendritic reticulum cell differentiation. A report of 4 cases. Am J Pathol 1986, 122(3):562-572.

4. Li L, Shi YH, Guo ZJ, Qiu T, Guo L, Yang HY, Zhang X, Zhao XM, Su Q: Clinicopathological features and prognosis assessment of extranodal follicular dendritic cell sarcoma. World J Gastroenterol 2010, 16(20):2504-2519.

5. De Pas T, Spitaleri G, Pruneri G, Curigliano G, Noberasco C, Luini A Andreoni B, Testori A, de Braud F: Dendritic cell sarcoma: an analytic overview of the literature and presentation of original five cases. Crit Rev Oncol Hematol 2008, 65(1):1-7.

6. Perez-Ordonez B, Erlandson RA, Rosai J: Follicular dendritic cell tumor: report of 13 additional cases of a distinctive entity. Am J Surg Pathol 1996, 20(8):944-955.

7. Efune G, Sumer BD, Sarode VR, Wang HY, Myers LL: Interdigitating dendritic cell sarcoma of the parotid gland: case report and literature review. Am J Otolaryngol 2009, 30(4):264-268.

8. Kondo T: A case of lipomatous pleomorphic adenoma in the parotid gland: a case report. Diagn Pathol 2009, 4:16.

9. Bersch C, Back W: Primary sebacous adenoma of the salivary glands - a rare differential diagnosis: report of a case. Diagn Pathol 2007, 2(Suppl 1):16.

10. Aboujaoude R, Alvarez JR, Alvarez M, Al-Khan A: Follicular dendritic cell sarcoma in pregnancy: case report and review of the literature. Am J Perinatol 2006, 23(8):459-461.

11. Amiri-Kordestani L, Priebat D, Chia SH: Follicular dendritic cell sarcoma of the neck: case report and review of current diagnostic and management strategies. Ear Nose Throat J 2010, 89(7):E14-17.

12. Androulaki A, Liapis G, Alexandrou P, Lazaris AC: Retroperitoneal follicular dendritic cell sarcoma. Int J Hematol 2006, 84(1):2.

13. Aydin E, Ozluoglu LN, Demirhan B, Arikan U: Follicular dendritic cell sarcoma of the tonsil: case report. Eur Arch Otorhinolaryngol 2006, 263(12):1155-1157.

14. Azim HA, Elsedewy E, Azim HA Jr: Imatinib in the treatment of follicular dendritic sarcoma: a case report and review of literature. Onkologie 2007, 30(7):381-384

15. Boldin I, Brix-Grunwald G, Scarpatetti MM, Beham-Schmid C, Klein A: Interdigitating dendritic cell sarcoma of the eyelid with a rapidly fatal course. Arch Ophthalmol 2008, 126(5):738-740

16. Cano JR, Cerezo F, Gonzalez A, Marchal T, Salvatierra A: [Follicular dendritic cell tumour in the anterior mediastinum]. Cir Esp 2009, 85(4):254-256.

17. Chera BS, Orlando C, Villaret DB, Mendenhall WM: Follicular dendritic cell sarcoma of the head and neck: case report and literature review. Laryngoscope 2008, 118(9):1607-1612.

18. Choi JW, Lee JH, Kim A, Kim CH, Chae YS, Kim I: Follicular dendritic cell sarcoma arising in the dura mater of the spine. Arch Pathol Lab Med 2006, 130(11):1718-1721

19. Choi BS, Baek JH, Shin YM, Kim JH, Kim HW, Lee SJ, Cha HJ: Follicular dendritic cell sarcoma: a case report and review of the literature. Cancer Res Treat 2010, 42(2):121-124. 
20. Clement $P$, Saint-Blancard P, Minvielle F, Le Page P, Kossowski M: Follicula dendritic cell sarcoma of the tonsil: a case report. Am J Otolaryngol 2006, 27(3):207-210

21. Cossu A, Deiana A, Lissia A, Dedola MF, Cocco L, Palmieri G, Tanda F: Synchronous interdigitating dendritic cell sarcoma and B-cell small lymphocytic lymphoma in a lymph node. Arch Pathol Lab Med 2006 130(4):544-547.

22. Cyriac S, Praveenkumar D, Majhi U, Sagar TG: Follicular dendritic cell sarcoma of the neck with an aggressive and fatal course. J Cancer Res Ther 2010, 6(1):114-116

23. Denning KL, Olson PR, Maley RH Jr, Flati VR, Myers JL, Silverman JF: Primary pulmonary follicular dendritic cell neoplasm: a case report and review of the literature. Arch Pathol Lab Med 2009, 133(4):643-647.

24. Diaz de Liano A, Garde C, Artieda C, Yarnoz C, Flores L, Ortiz H: Intraabdominal follicular dendritic cell sarcoma. Clin Transl Oncol 2006, 8(11):837-838

25. Duan GJ, Wu F, Zhu J, Guo DY, Zhang R, Shen LL, Wang SH, Li Q, Xiao HL, Mou $\mathrm{JH}$, et al: Extranodal follicular dendritic cell sarcoma of the pharyngeal region: a potential diagnostic pitfall, with literature review. Am J Clin Pathol 133(1):49-58.

26. Encabo RS, McHugh J, Carrau RL, Kassam A, Heron D: Follicular dendritic cell sarcoma of the nasopharynx. Am J Otolaryngol 2008, 29(4):262-264.

27. Eun YG, Kim SW, Kwon KH: Follicular dendritic cell sarcoma of the tonsil Yonsei Med J 2010, 51(4):602-604.

28. Fan YS, Ng WK, Chan A, Chan GS, Tsang J, Chim CS, Ip P: Fine needle aspiration cytology in follicular dendritic cell sarcoma: a report of two cases. Acta Cytol 2007, 51(4):642-647.

29. Fraser CR, Wang W, Gomez M, Zhang T, Mathew S, Furman RR, Knowles DM, Orazi A, Tam W: Transformation of chronic lymphocytic leukemia/small lymphocytic lymphoma to interdigitating dendritic cell sarcoma: evidence for transdifferentiation of the lymphoma clone. Am J Clin Pathol 2009, 132(6):928-939.

30. Gach JE, Carr RA, Charles-Holmes R: Nodal follicular dendritic cell sarcoma of the axilla presenting as cellulitis. $\mathrm{Br} J$ Dermatol 2006, 154(1):177-178.

31. Gong QX, Fan QH, Zhou ZS, Zhang ZH, Yu MN, Wang Z, Wang C, Zhang WM: [Inflammatory pseudotumor-like follicular dendritic cell tumor of spleen]. Zhonghua Bing Li Xue Za Zhi 2008, 37(1):40-44.

32. Gordon MK, Kraus M, van Besien K: Interdigitating dendritic cell tumors in two patients exposed to topical calcineurin inhibitors. Leuk Lymphoma 2007, 48(4):816-818.

33. Granados R, Aramburu JA, Rodriguez JM, Nieto MA: Cytopathology of a primary follicular dendritic cell sarcoma of the liver of the inflammatory pseudotumor-like type. Diagn Cytopathol 2008, 36(1):42-46.

34. Han HS, Lee OJ, Lim SN, An JY, Lee KM, Choe KH, Lee KH, Kim ST: Extranodal interdigitating dendritic cell sarcoma presenting in the pleura: a case report. J Korean Med Sci 2011, 26(2):304-307.

35. Hartert M, Strobel P, Dahm M, Nix W, Marx A, Vahl CF: A follicular dendritic cell sarcoma of the mediastinum with immature $T$ cells and association with myasthenia gravis. Am J Surg Pathol 2010, 34(5):742-745.

36. Hollingsworth J, Cooper WA, Nicoll KD, Wills EJ, Thiruvilangam V, Lee CS, Scolyer RA: Follicular dendritic cell sarcoma of the lung: a report of two cases highlighting its pathological features and diagnostic pitfalls. Pathology 2011, 43(1):67-70.

37. Ishihara $S$, Honda $Y$, Asato $T$, Nonaka M, Nakagawa S, Hirashima K, Hayashi N, Baba H, lyama K: Interdigitating dendritic cell sarcoma of the ileum recurred in multiple lymph nodes and duodenum three years after operation without chemotherapy. Pathol Res Pract 2010, 206(7):514-518.

38. Jiang L, Admirand JH, Moran C, Ford RJ, Bueso-Ramos CE: Mediastinal follicular dendritic cell sarcoma involving bone marrow: a case report and review of the literature. Ann Diagn Pathol 2006, 10(6):357-362.

39. Jo S, Babb MJ, Hilsinger RL Jr: Interdigitating dendritic cell sarcoma of cervical lymph nodes. Arch Otolaryngol Head Neck Surg 2006, 132(11):1257-1259.

40. Kanaan H, Al-Maghrabi J, Linjawi A, Al-Abbassi A, Dandan A, Haider AR: Interdigitating dendritic cell sarcoma of the duodenum with rapidly fatal course: a case report and review of the literature. Arch Pathol Lab Med 2006, 130(2):205-208

41. Kapucuoglu N, Percinel S, Ventura T, Lang R, Al-Daraji W, Eusebi V: Dendritic cell sarcomas/tumours of the breast: report of two cases. Virchows Arch 2009, 454(3):333-339.
42. Karaman E, Saritzali G, Kilic E, Korkut N, Enver O: Follicular dendritic cell sarcoma of the parotid gland recurring 6 times within 12 years. $J$ Craniofac Surg 2009, 20(6):2171-2172.

43. Khalid S, Yaqoob N, Pervez S: Follicular dendritic cell sarcoma of lymph node-a rare entity. J Pak Med Assoc 2006, 56(3):137-139.

44. Kim SY, Kang JH, Chun SH, Chang MH, Kim YS, Lee SN, Kim MS, Kang CS: Interdigitating dendritic cell sarcoma of the tonsil. Asia Pac J Clin Oncol 2010, 6(3):144-148.

45. Kim H, Park CM, Jeon YK, Yoo IR, Song SW, Goo JM, Lee HJ: Computed Tomography and 18F-fluoro-2-deoxyglucose Positron Emission Tomography Findings of Primary Pulmonary Follicular Dendritic Cell Sarcoma: Case Report and a Literature Review. J Thorac Imaging 2011.

46. Kovacs RB, Sattar HA, Krausz T, Kas J, Berta M, Sapi Z: Primary follicular dendritic cell sarcoma of the lung. Histopathology 2006, 49(4):431-433.

47. Kure K, Khader SN, Suhrland MJ, Ratech H, Grossberg R, Oktay MH: Fine needle aspiration of follicular dendritic cell sarcoma in an HIV-positive man: a case report. Acta Cytol 2010, 54(5):707-711.

48. Leipsic JA, McAdams HP, Sporn TA: Follicular dendritic cell sarcoma of the mediastinum. AJR Am J Roentgenol 2007, 188(6):W554-556.

49. Li J, Duan MH, Han B, Zhang W, Zhou DB, Zhao YQ, Shen T: [Dendritic cell sarcoma: 4 cases report with literature review]. Zhonghua Xue Ye Xue Za Zhi 2008, 29(4):263-266

50. Liu X, Deng Y, Zhang X, Mukherjee R, Huang W, Zhang G, Wang H, Li X: Interdigitating dendritic cell sarcoma following adult liver transplantation: case report and literature review. Pathol Oncol Res 2011, 17(2):397-402.

51. Long-Hua Q, Qin X, Ya-Jia G, Jian W, Xiao-Yuan F: Imaging findings of follicular dendritic cell sarcoma: report of four cases. Korean J Radiol 2011, 12(1):122-128.

52. Low SE, Menasce LP, Manson CM: Follicular dendritic cell sarcoma: a rare tumor presenting as an abdominal mass. Int J Surg Pathol 2007 15(3):315-317.

53. Ludwig A: [Extranodal follicular dendritic cell sarcoma of the tonsils]. Hno 2006, 54(9):701-704

54. Majhi U, Shirley S, Murhekar K: Follicular dendritic cell sarcoma of oral cavity: report of 2 cases. Indian J Pathol Microbiol 2007, 50(3):545-547.

55. Martins PN, Reddy S, Martins AB, Facciuto M: Follicular dendritic cell sarcoma of the liver: unusual presentation of a rare tumor and literature review. Hepatobiliary Pancreat Dis Int 2011, 10(4):443-445.

56. Miyagi T, Nagasaki A, Shinzato O, Ohshima K, Takasu N: [Interdigitating dendritic cell sarcoma/tumor-a case report]. Gan To Kagaku Ryoho 2007, 34(3):469-471

57. Padilla-Rodriguez AL, Bembassat M, Lazaro M, Ortiz-Hidalgo C: Intraabdominal follicular dendritic cell sarcoma with marked pleomorphic features and aberrant expression of neuroendocrine markers: report of a case with immunohistochemical analysis. Appl Immunohistochem $\mathrm{Mol}$ Morphol 2007, 15(3):346-352.

58. Pailoor J, lyengar KR, Chan KS, Sumithra S: Follicular dendritic cell sarcoma of inguinal lymph node-a case report. Malays J Pathol 2008, 30(2):115-119.

59. Pisani F, Marino M, Sentinelli S, Petti MC: Follicular dendritic cell sarcoma of the neck: report of a case treated by surgical excision and COP plus (PEG)-liposomal doxorubicin. J Exp Clin Cancer Res 2008, 27:33.

60. Pizzi M, Ludwig K, Palazzolo G, Busatto G, Rettore C, Altavilla G: Cervical follicular dendritic cell sarcoma: a case report and review of the literature. Int J Immunopathol Pharmacol 2011, 24(2):539-544.

61. Romero-Guadarrama MB, Reyes-Posada O, Hernandez-Gonzalez MM, DuranPadilla MA: Follicular dendritic cell sarcoma/tumor: 2 cases of a rare tumor of difficult clinical and pathological diagnosis. Ann Diagn Pathol 2009, 13(4):257-262.

62. Sander B, Middel P, Gunawan B, Schulten HJ, Baum F, Golas MM, Schulze F, Grabbe E, Parwaresch R, Fuzesi L: Follicular dendritic cell sarcoma of the spleen. Hum Pathol 2007, 38(4):668-672

63. Shen SC, Wu CC, Ng KF, Wu RC, Chen HM, Chen TC: Follicular dendritic cell sarcoma mimicking giant cell carcinoma of the pancreas. Pathol Int 2006, 56(8):466-470.

64. Shen DP, Ni XZ, Yin XL, Wu ZY: Clinical and pathological features of follicular dendritic cell sarcoma of appendix: a case report. Chin Med J (Engl) 2009, 122(13):1595-1597.

65. Silver AL, Faquin WC, Caruso PA, Deschler DG: Follicular dendritic cell sarcoma presenting in the submandibular region in an 11 year-old. Laryngoscope 2011, 120(Suppl 4):S183. 
66. Soriano AO, Thompson MA, Admirand JH, Fayad LE, Rodriguez AM, Romaguera JE, Hagemeister FB, Pro B: Follicular dendritic cell sarcoma: a report of 14 cases and a review of the literature. Am J Hematol 2007, 82(8):725-728.

67. Suhail Z, Musani MA, Afaq S, Zafar A, Ahmed Ashrafi SK: Follicular dendritic cell sarcoma of tonsil. J Coll Physicians Surg Pak 2010, 20(1):55-56.

68. Suzuki N, Katsusihma H, Takeuchi K, Nakamura S, Ishizawa K, Ishii S, Moriya T, DeCoteau JF, Miura I, Ichinohasama R: Cytogenetic abnormality 46, XX, add(21)(q11.2) in a patient with follicular dendritic cell sarcoma. Cancer Genet Cytogenet 2008, 186(1):54-57.

69. Tokyol C, Yilmaz MD, Ekici O, Aktepe F: Follicular dendritic cell sarcoma: a case report. Acta Cytol 2008, 52(2):235-239.

70. Tu XY, Sheng WQ, Lu HF, Wang J: [Clinicopathologic study of intraabdominal extranodal follicular dendritic cell sarcoma]. Zhonghua Bing Li Xue Za Zhi 2007, 36(10):660-665.

71. Vaideeswar P, George SM, Kane SV, Chaturvedi RA, Pandit SP: Extranodal follicular dendritic cell sarcoma of the tonsil - case report of an epithelioid cell variant with osteoclastic giant cells. Pathol Res Pract 2009, 205(2):149-153.

72. Vives S, Fernandez MT, Lopez de Castro PE, Ribera JM: [Interdigitating dendritic cell sarcoma with localization to the lung]. Med Clin (Barc) 2006, 126(14):559.

73. Voigt LP, Hmidi A, Pastores SM, Maki RG, Carlson DL, Bains MS, Halpern NA: Management dilemmas due to a paratracheal follicular dendritic cell tumor. Ann Thorac Surg 2006, 82(5):1898-1900.

74. Wang LF, Wang RF, Wang ZC, Han W, Mei HL, Liu M: [Follicular dendritic cell sarcoma of stomach: report of a case]. Zhonghua Bing Li Xue Za Zhi 2008, 37(3):210-211.

75. Wang Xl, Zhang S, Thomas JO, Adegboyega PA: Cytomorphology, ultrastructural, and cytogenetic findings in follicular dendritic cell sarcoma: a case report. Acta Cytol 2010, 54(5 Suppl):759-763.

76. Wang H, Su Z, Hu Z, Wen J, Liu B: Follicular dendritic cell sarcoma: a report of six cases and a review of the Chinese literature. Diagn Pathol 2010, 5:67.

77. Wang $Q, A n L$, Cui N, Sha J, Zhu D: [Follicular dendritic cell sarcoma: a case report and review of literature]. Lin Chung Er Bi Yan Hou Tou Jing Wai Ke Za Zhi 2011, 25(3):100-102.

78. Wu Q, Liu C, Lei L, Yan X, Wang B, Liu X, Yv L, Lv Y: Interdigitating dendritic cell sarcoma involving bone marrow in a liver transplant recipient. Transplant Proc 2010, 42(5):1963-1966.

79. Yakushijin Y, Shikata H, Kito K, Ohshima K, Kojima K, Hato T, Hasegawa H, Yasukawa M: Follicular dendritic cell tumor as an unknown primary tumor. Int J Clin Oncol 2007, 12(1):56-58

80. Yamada Y, Haga H, Hernandez M, Kubota KC, Orii F, Nagashima K Matsuno $Y$ : Follicular dendritic cell sarcoma of small intestine with aberrant T-cell marker expression. Pathol Int 2009, 59(11):809-812.

81. Yang GC, Wang J, Yee HT: Interwoven dendritic processes of follicular dendritic cell sarcoma demonstrated on ultrafast papanicolaou-stained smears: a case report. Acta Cytol 2006, 50(5):534-538.

82. Yu L, Yang SJ: Primary Follicular Dendritic Cell Sarcoma of the Thyroid Gland Coexisting With Hashimoto's Thyroiditis. Int I Surg Pathol 2009.

83. Zhang ZX, Cheng J, Shi QL, Ma J, Zhou XJ, Zhou HB, Ma HH: [Follicular dendritic cell sarcoma: a clinicopathologic study of 8 cases]. Zhonghua Bing Li Xue Za Zhi 2008, 37(6):395-399.

84. Zhong GP, Sun WY, Gan MF, Yuan MC: [Follicular dendritic cell sarcoma: a clinicopathologic study of five cases]. Zhonghua Bing Li Xue Za Zhi 2006, 35(10):612-615.

85. Zhou ZY, Sun RC, Yang SD, Liang JB, Rui J, Pan MH: Interdigitating dendritic cell tumor of the lymph node in the right submaxillary region: a case report and review of the literature. Int I Surg Pathol 2011, 19(1):88-92.

86. Zivkovic V, Basic M, Gligorijevic J, Pavlovic V, Lazarevic V, Petrovic A: Follicular dendritic cell sarcoma in the lymph nodes of the neck. Bratis Lek Listy 2007, 108(8):368-370.

doi:10.1186/1746-1596-6-94

Cite this article as: Schraven et al.: Dendritic cell tumor in a salivary gland lymph node: a rare differential diagnosis of salivary gland neoplasms. Diagnostic Pathology 2011 6:94

\section{Submit your next manuscript to BioMed Central and take full advantage of:}

- Convenient online submission

- Thorough peer review

- No space constraints or color figure charges

- Immediate publication on acceptance

- Inclusion in PubMed, CAS, Scopus and Google Scholar

- Research which is freely available for redistribution

Submit your manuscript at www.biomedcentral.com/submit 